\title{
Valuing the Waiver: The Real Beauty of Ex Ante over Ex Post
}

Robert C. Hockett

Follow this and additional works at: https://scholarlycommons.law.case.edu/caselrev

Part of the Law Commons

\section{Recommended Citation}

Robert C. Hockett, Valuing the Waiver: The Real Beauty of Ex Ante over Ex Post, 57 Case W. Rsrv. L. Rev. 381 (2007)

Available at: https://scholarlycommons.law.case.edu/caselrev/vol57/iss2/9

This Symposium is brought to you for free and open access by the Student Journals at Case Western Reserve University School of Law Scholarly Commons. It has been accepted for inclusion in Case Western Reserve Law Review by an authorized administrator of Case Western Reserve University School of Law Scholarly Commons. 


\title{
VALUING THE WAIVER: THE REAL BEAUTY OF EX ANTE OVER Ex Post
}

\author{
Robert C. Hockett $t^{\dagger}$
}

First, thank you to Professor Geoffrey Miller and indeed all of my co-panelists for their stimulating remarks, and to Professor Dent, Dean Simson, and the students of Case Western Reserve University School of Law for your invitation to take part in this year's George A. Leet Business Law Symposium. It is a great pleasure and, indeed, a great honor to be here with so many distinguished practitioners, scholars, and participants.

In view of my limited time this morning, I am going to confine myself to saying just a bit about one particular feature that I find particularly attractive about not only Professor Miller's very interesting proposal, but also about many cognate proposals-indeed all proposals of a particular kind of which Professor Miller's is one elegant instance-namely, what I shall call "voluntary, ex ante waiver" proposals. And in view of this feature I am going to recommend, in conclusion, that we consider experimenting with a variety of proposals of this kind.

First to situate my remarks: what I find most attractive about voluntary, ex ante waiver proposals is best understood by reference to several particularly interesting features of the current public debate over corporate attorney-client privilege and the work-product doctrine. The features that I have in mind are directly traceable, I believe, to a cluster of acute uncertainties-conceptual, epistemic, and just plain empirical uncertainties-that afflict all of the current discussions. And the great beauty of ex ante waiver proposals, I think, is precisely that they offer us means of neutralizing, dissolving, or sidestepping those very uncertainties.

$\dagger$ Assistant Professor of Law, Cornell Law School. Warm thanks to Geoff Miller, George Dent, Gary Simson, and the participants in the 2006 George A. Leet Business Law Symposium at Case Western Reserve University School of Law. Many thanks also to the editors and staff of the Case Western Reserve Law Review, in particular Elizabeth LeBlanc. 
I begin first by noting that the current debate over attorney-client privilege and the work-product doctrine in the corporate context is fraught with a truly surprising degree of overstatement and, indeed, downright irony. Consider, for instance, these two topical examples:

Presently the executive branch-in particular the Department of Justice (not the SEC, of course, Professor Goldschmid and Mr. Humes!) - oftentimes speaks in terms reminiscent of those commonly employed by advocates of the inquisitorial, rather than the adversarial, system of justice when discussing the privilege. You hear advocates of pre-trial privilege-waiver referring to the importance of "getting at the truth," and of how privilege gets in the way of that desideratum. Or you hear the old saw that if one really has nothing to hide, then one should not be concerned about retaining the privilege in any event.

The irony here, of course, is that this is the same branch of government that has been notorious for its resistance to public scrutiny of its own internal operations-on precisely the grounds commonly proffered in defense of the privilege. Hence, for example, when members of the press and public interest groups sought to learn who the members of the Vice President's "energy task force" were a few years back, the answer given was that disclosure of this information might chill the frank, internal deliberation necessary to the proper functioning of the task force. (That of course sounds a good bit like what advocates of the privilege in the corporate context say, as will be borne out further in my second example, just below.) And so the same branch of government that impugns privilege as a refuge of scoundrels' appeals, in rebuffing the press and the public, emphasizes the importance of confidentiality and the privilege that protects it. Irony number one.

Now consider this one: some members of the corporate bar, and here I am thinking, in particular, of the hearings held by the ABA task force on attorney-client privilege and the work-product doctrine in the last several years, have spoken as though compliance with the law and the assurance of such compliance were always best viewed as purely internal matters. The firms "really want to abide by the law," we are assured, and will be better positioned to do so if employees and all others internal to firm are able to speak frankly and with full candor (like the members of the Vice President's "energy task force"!), without fear of excessive scrutiny, reprisal, or prosecution to inside counsel. "So," these folk are in effect saying, "we really think that the public interest in corporate right-doing is best served by theprivately employed-privilege." 
That is, of course, somewhat ironic in itself. But much more ironic is the fact that some members of the bar in some of these ABA task force proceedings I have mentioned are now invoking the specter of an all-powerful, inquisitorial government systematically stripping firms and their officers of cherished and time-honored corporate rights in the wake of Enron and other high-profile scandals. They sound almost like Lord Coke, or the Boston Tea Party patriots. If you have not read these proceedings, I heartily recommend some of them for a good chortle: you can actually read members of the corporate bar talking in terms that we associate with the public advocacy of Amy Goodman, Noam Chomsky, or the ACLU. This is irony number two.

Now a crowning irony in the pair of positions I have just sketched, of course, is, first, that surely the past five years have afforded us at least some reason to be skeptical about the adequacy of internal, private policing by firms alone to ensure that upper level employees are not engaged in what amounts to public (i.e., criminal) wrongdoing. And second, it also seems a bit fanciful, to put the point mildly, to suggest that the executive branch, particularly the current personnel occupying it, are out to "stick it to the corporate man," so to speak. Or are "out to get" businesses, or are plotting some systematic stripping, from American businesses across the board, of all cherished prerogatives and traditional rights. The current administration might have appreciated the contributions made by Ralph Nader to the 2000 elections, but they are probably not about to name him to an SEC commissionership.

So again, a bit of irony, and a bit of overstatement in what has become the customary rhetoric surrounding recent corporate scandals and their legal fallout. But now the question becomes, how do we account for this? Is this just a case of the usual gassing that accompanies vigorous public discussion in the wake of scandal or controversy, or is there something perhaps that is a bit more unique to the present context?

It seems to me that there a number of possible ways to account for the ironies I have mentioned, some of them admittedly familiar across contexts, but others indeed a bit more unique to the present context. It is in connection with the latter that I find ex ante waiver proposals so very intriguing.

Now, as for the more prosaic explanations for the ironies I have cited, first of all, admittedly, part of the story must lie in the nature of contemporary public discourse itself, considered more generally. This is a discourse that tends familiarly to focus on extreme situations, 
sensational stories, and dramatic archetypes, whose significance can be telegraphed quickly in sound-byte form. So, of course, we get simplified slogans and hyperbole and nightmare scenarios painted before us-not just in the present, corporate scandal context, but in any context involving public controversy.

Second, and again admittedly, if you are an advocate of a position, I suppose you are naturally going to tend to emphasize the horror stories, or the most dramatic exemplars, of what those who share your position find frightful. You will naturally tend to do that in any advocative context, not just the present, corporate scandal context. So this, too, is hardly surprising.

And yet, nevertheless, there seems to me to be one feature unique to the present context, the context of corporate wrongdoing and the role of corporate counsel, that I suspect plays a more important role in accounting for the particular ironies and overstatements that $I$ have briefly cited. This unique causal factor has to do with something peculiar to the nature of corporate conduct and misconduct itself, along with its aftermath. It also has to do with the nature of the attorney's canonically "dual role" as a "zealous advocate" for the client on the one hand, and as an "officer of the court" or of the justice system on the other. In short, I think what we have is a particularly acute information problem, a largely empirical information problem, in the context of corporate wrongdoing and the investigation of corporate wrongdoing. This problem, I believe, uniquely lends itself to overstatement in advocacy of one side or the other when we talk about the propriety or otherwise of waiving attorney-client privilege or the work-product doctrine.

Let me illustrate by first very quickly rehearsing-though in a public-interest-weighted way-the classic arguments in favor of attorney-client privilege and the work-product doctrine on the one hand and those against them on the other. As I do so, please note how the commonly taken positions in respect of these issues connect to acute information problems. For it is this feature, I believe, that ultimately lends ex ante privilege-waiver proposals their valid claim to our attention.

First, on the side of privilege, what is the public interest commonly invoked? The idea, is it not, is that you facilitate ex ante compliance with the law within the firm by enabling corporate employees to speak fully and frankly, in full candor, with in-house counsel. An oftunstated premise here is that the law is fraught with ambiguity. It often is difficult, in consequence, to know whether one is complying. And so in-house counsel require frank disclosure by personnel of 
their deeds, both actual and contemplated. And this disclosure is in turn facilitated by the privilege.

Next, what is the public interest commonly thought to underwrite-waiver or full availability of all pertinent information to prosecutors and plaintiffs? Well, it is that waiver of privilege facilitates ex-post rectification of wrongs, is it not? Because, as the argument goes, you cannot do justice without getting at the truth. (And indeed, as this argument sometimes adds, if justice then is done ex post in this way we are also going to provide the right set of incentives ex ante to future potential wrongdoers.)

Now, imagine two cases in which you have no ambiguity, no uncertainty as to what is actually occurring or has actually occurred at all. The first such case is one in which all personnel within the firm are "certainly innocent," so to speak; there is clearly no wrongdoing afoot; we know this with full confidence. In this case (should it ever actually be encountered), it is very easy to argue that the privilege and its rationale are simply unimplicated. For here there is, by hypothesis, simply nothing to hide or to seek advice about. As a potential defendant in this case, you have no worries. You have literally nothing to hide, so you have no need for the privilege. "The privilege is only there to hide wrongdoing or, in the best case, to hide something embarrassing, the wrongness or rightness of which is vague and uncertain," one might say, "and since we have no uncertainty in this case there is accordingly no need of the privilege." This is one extreme argument on behalf of waiver advocates to which the hypothetical situation involving certainty of innocence lends itself.

Here is another extreme argument that the same condition offers to advocates not of waiver, but of the privilege: "If we truly have certain innocence and nothing that arguably constitutes wrongdoing here, then there is nothing for the public to gain from private waiver of the privilege. You are not going to learn anything that is going to enable you better to enforce the law ex post. All you are going to learn is that we are innocent. So, you have really no need for our waiving the privilege."

In the case of true certainty of innocence, then, there is not a very strong argument for the privilege or for waiver of the privilege. Good arguments for one or the other gain traction only in the face of uncertainty of innocence, owing either to uncertainty about what actually is occurring or has occurred, or to uncertainty about what the law actually requires. The value, then, of either the privilege or its waiver might be contingent precisely upon uncertainty of innocence. In the absence of such uncertainty, i.e., where innocence is certain, it is al- 
together easy to level absolutist, simplistic cookie-cutter style arguments against privilege and waiver alike. And so advocates of the two positions, not surprisingly, typically fall back on scenarios involving certainty and then level such mutually canceling absolutist arguments, in turn giving rise to ironies of the kind cited.

Matters are somewhat similar in the case of certain guilt rather than certain innocence, though now in a more one-sided way: here it is very easy to argue both, on behalf of the private defendant, that the privilege is crucial (though of course not legitimately so, from the point of view of the public interest) and, on behalf of the private plaintiff or the general public, that waiver of the privilege is crucial. The defendant of course wants the privilege in this case for obvious reasons. The plaintiff or prosecutor, for her part, then says by way of rejoinder, "the only reason you desire the privilege is simply to conceal the evidence of your guilt. By hypothesis, the wrongdoing is or was indeed wrong and is being, or has already been done; hence, you, the hypothetically guilty party, cannot plausibly claim that you require the privilege in order to facilitate frank internal discussion with a view to complying with the law." So here, in the case of certain guilt, we again have a knock-down argument, an absolutist argument, though this time in favor of waiver alone rather than in favor of privilege. It is accordingly not altogether surprising that advocates of waiver would often fall back upon assumed (though unstated) scenarios of this sort.

But now here, of course, is where our problem lies: we seldom, if ever, actually have clear innocence or clear guilt, at least not at the time of the investigation, and typically not even after then. So it really will not do to argue on the basis of cases of "clear" innocence or "clear" guilt for the privilege or for waiver of the privilege. What you typically have in these cases is a great deal of uncertainty concerning what has actually happened. And/or you have fuzziness, so to speak, concerning what the law actually required or requires. So there is uncertainty about "the facts," and/or unclarity about "the law" and its implications.

As to the latter-the "legal fuzz," so to speak-you commonly hear advocates for firms saying that there has been a great welter of regulatory growth, particularly post-Enron, and that in consequence it is very difficult for counsel and for other personnel within firms to know whether particular completed or contemplated actions are or are likely to be compliant with the law or not. And it is plausible in the case of this form of legal uncertainty to claim that you really do require that kind of privilege-assisted frankness of internal discussion in 
order to determine whether you ought to be acting differently in order to comply with the law.

As to the matter of factual uncertainty, we often hear that there is great unclarity as to what actually has happened in the wake of some complex scandal such as that said to have occurred at Enron or WorldCom. Partly that owes to the complexity of the transactions themselves; and partly it owes, relatedly, to the clever tracks-covering that in which the malfeasant parties are likely to have engaged. There is a lot of paper to go through, so to speak, and possibly a lot has been shredded. So "the facts" can be as unclear as the law in these cases.

But uncertainties concerning law and fact or event, as common as these are likely to be in complex corporate scandal cases, are not the only ones that plague us. There are at least three additional sources of relevant uncertainty that likewise account, I suspect, for much of the hyperbole and ultimate irony in the contemporary debate over corporate attorney-client privilege, work product, and waiver:

First, as I mentioned in passing earlier, there are uncertainties rooted in the role-ambiguity inherent in the role of any counsel operating within our adversarial system of justice. Any counsel, including any corporate counsel, faces uncertainties between the requirements of zealous advocacy for the client on the one hand and serving as a responsible officer of the court and the justice system on the other.

Second, there are potential uncertainties stemming from a species of conceptual ambiguity, in some cases, between "information," which according to doctrine of course is not privileged, on the one hand, and mere "advice" or lawyerly "opinion," to which the privilege and work product doctrine actually attach, on the other. Sometimes, as we all know, it is not easy to draw a bright demarcation between these.

Finally, third, there is potential ambiguity, in the case of ex post waiver of the privilege, between bona fide voluntariness of the waiver on the one hand and coercion of one or another kind or degree on the other. That is so in particular because, in the cases we are talking about-namely, waiver that is undertaken in order to be deemed cooperative in the already commenced investigation of a crime alleged already to have been committed-one is seeking the benefit of lighter sentencing. This is an inherently coercive context. And so, unsurprisingly, corporate counsel often have remarked that even when waiver might be "voluntary" in some metaphysical sense in these cases, it often does not feel that way in any motivational sense.

Now, in all of these cases, in which there are systematic ambiguities and uncertainties, it would seem pretty clear that there might in- 
deed be some room to benefit - for the firm to benefit and for the public policy interest in corporate compliance with the law to be advanced-from the privilege. The claim that the privilege is salutary is at least plausible in these cases; it cannot be dismissed out of hand by absolutist argumentation predicated on hypothetical certainties that in fact are not present. One can make a colorable claim, for example, that if you do encourage free and candid discussion within the firm before possible wrongdoing takes place then you really might, to some degree or another, enhance the likelihood ex ante that the firm is going to comply with the law more effectively.

Symmetrically, in these cases where there is pervasive ambiguity and uncertainty of the sorts indicated above, it is also entirely plausible, though again, not certainly correct in each case, to suggest that waiver of the privilege, and full revelation of all pertinent information to the prosecutors or the plaintiffs, might indeed afford some benefit to the public interest. One can make a colorable claim, for example, that you more fully enable those who are prosecuting legitimate claims to find evidence of bad faith or good faith this way. There is more opportunity for red flags to be raised, so that those who are investigating are able to ascertain where to look less expensively. And the consequently successful investigations and prosecutions ex post play their own role, of course, in encouraging ex ante compliance.

But now, do you see the problem here? There are colorable claims on both sides, the privilege and the waiver sides, in precisely the situations that we are typically in fact faced with and thus actually interested in-those where there is ambiguity and/or uncertainty. But how do you draw the appropriate balance in these cases? How do you separately weigh, then commensurate, then comparatively weigh (i.e., "balance") the comparative costs and benefits in these cases-the real, rather than the caricatured, cases that we find in the public debates? What common metric is there for determining "how much gain" is likely to be realized by strict honoring of the privilege, on the one hand, or by liberal waiver of the privilege (or through full disclosure of even colorably privileged information to prosecutors or plaintiffs) once an investigation is underway, on the other?

Our want of an answer to the question I posed accounts, I suspect, in very large measure for the caricature and irony of the debate over privilege and waiver described above. Our multiple sources of ambiguity and uncertainty, all culminating in the grandest informational lacuna of them all-the lack of a scalar metric along which comparatively to value the vectors of benefits and burdens posed by the privilege and its waiver ex post-leaves us trapped with this ongoing di- 
lemma and consequently interminable cycle of absolutist argumentation, platitude, irresoluble controversy, and ongoing rhetorical irony.

Now it is precisely here, I think, that ex ante waiver proposals prove so intriguing. To begin with, what we are talking about here is indeed ex ante waiver, which of course means that it straightforwardly is not coerced-at least not in the particularized, hence poignantly acute, manner that so troubles corporate counsel in the current debate. You do not have any danger here that the waiver is being made under a sword wielded by the court or a prosecutor or a government agency in circumstances where penalties already are imminent for a particular person or group of persons. There is little if any ambiguity about voluntariness in this ex ante case.

But now rather more generally and I think more importantly, the ex ante waiver promises to eliminate that "grandest informational lacuna of them all" that I cited a moment ago-the valuational uncertainty stemming from the multiple sources of value in both the privilege and its waiver. Insofar as there is measuring to be done along a common metric of what the comparative values of waiver privilege are, what better or more salient aggregator of that sort of valuational information is there than our deep, liquid, and by and large informationally efficient securities market itself? For, in the final analysis, isn't the "value" that ultimately concerns us here, when we speak of the corporate governance regime and its optimal policing, the value of firms to their owners? Is not the most immediately, if not indeed exclusively, relevant "public" here the investing public, the shareholding public? And are not the securities markets precisely those fora in which this sort of valuation takes place? And would not the decision to waive privilege ex ante, or to retain it, simply be just one more source of such value, best determined, from firm to firm, by an informationally efficient market for firms' shares?

At least provisionally speaking, I am very much tempted to think that the answer to all of these questions is "yes." And so our answer to ex ante waiver proposals also should be, at least provisionally, "yes." Indeed, we ought seriously to consider the prospect of developing a full menu of possible waivers and partial waivers of the same general kind as that suggested by Professor Miller just before me. We ought to consider it seriously precisely because it offers means, at long last, of cutting through precisely all of that ambiguity, uncertainty, and consequent caricature-mongering, argument-cycling, and irony of which I took brief account in opening my discussion. Certainty of a sort - of the valuational sort that ultimately concerns usat last. If for no other reasons than these, I think one should treat vol- 
untary waiver proposals as worthy of serious consideration, experimentation, and econometric tracking no matter which side one currently occupies in the ongoing contemporary debate as to whether the privilege and work product doctrines should be strictly honored, on the one hand, or waivable on the other. For it looks as though we might, and for now I should emphasize "might," be able quite plausibly to both keep the cake and eat it now by saying: It should be strictly honored ex post, if and only if it has not been voluntarily waived ex ante. 